\title{
PEMANFAATAN JERUK PURUT (CITRUS HYSTRIX) SEBAGAI BIOLARVASIDA
}

\author{
Titik Lestari \\ Kementerian Kesehatan Politeknik Kesehatan Surakarta Jurusan Jamu
}

\begin{abstract}
Absctract: Citrus hystrix, Biolarvicides. Insectisides and pestisides were used as larvicides to control mosquito vector Aedes aegypti particularly. Some research suggested there had been a larvae resistance to pesticides. Biolarvicides with basic ingredients plant was another alternative that can be used. Lime (Citrus hystrix) was one of plants that often used as biolarvicides, both lits fruit and leaves. This paper aimed to know about chemical compound in lime and its potential as biolarvicidal. Research methods was literature review from several research journals. The results showed that the presence of coumpounds were essential oil, flavonoids, saponins, terpeesn, limonoids, citronellal, linalool, citronellol, acetate citronelil, kariofilin and geraniol. $L C_{50}$ of lime leaves as biolarvicides againts the third instar larvae of Aedes aegypti was 279.882 ppm, biolarvicides oxicity values ( $\left.L C_{90}\right)$ was $4000 \mathrm{ppm}$ with the lethal time $\left(L T_{90}\right)$ was 12.67 hours. Based on results of this study concluded that the presence of the chemical content of Citrus hystrix plant potential as biolarvicides.
\end{abstract}

\section{Keyword : Citrus Hystrix, Biolarvicides}

Abstrak: Citrus hystrix, Biolarvasida. Insektisida dan pestisida digunakan sebagai larvasida dalam pengendalian vektor nyamuk khususnya nyamuk Aedes aegypti. Beberapa penelitian menunjukkan telah terjadi resistensi larva terhadap pestisida. Biolarvasida dengan bahan dasar tumbuhan merupakan alternatif lain yang bisa digunakan. Tanaman yang sering digunakan salah satunya adalah jeruk purut (Citrus hystrix), baik dari buah maupun daunnya. Tujuan penulisan ini adalah mengetahui kandungan senyawa kimia pada tanaman jeruk purut dan potensinya sebagai biolarvasida. Metode penelitian secara studi pustaka dari beberapa jurnal penelitian. Hasil penelitian menunjukkan adanya senyawa minyak atsiri, flavonoid, saponin, terpen, limonoid, sitronelal, linalool, sitronelol, sitronelil asetat, kariofilin dan geraniol. $\mathrm{LC}_{50}$ dari minyak daun jeruk purut sebagai biolarvasida terhadap larva instar III nyamuk Ae. aegypti adalah $279,882 \mathrm{ppm}$, nilai toksisitas biolarvasida ( $\left.\mathrm{LC}_{90}\right)$ sebesar $4000 \mathrm{ppm}$ dengan masa letal $\left(\mathrm{LT}_{90}\right) 12.67 \mathrm{jam}$. Berdasarkan hasil penelitian dapat disimpulkan bahwa dengan adanya kandungan senyawa kimia maka tanaman jeruk purut berpotensi sebagai biolarvasida.

Kata Kunci: Citrus Hystrix, Biolarvasida

\section{PENDAHULUAN}

Salah satu negara tropis terbesar di dunia adalah Indonesia, dengan iklim tropis ini ada salah satu penyakit yang disebabkan oleh nyamuk Aedes aegypti yaitu Demam Berdarah Dengue (DBD). Epidemi penyakit ini muncul terutama disebabkan oleh perkembangbiakan dan 
penyebaran nyamuk Aedes aegypti sebagai vektor yang tidak terkendali (Ratnaningsih, et.al., 2010 dalam Adrianto, et.al., 2014).

Selain laju perkembangbiakan vektor yang tidak terkendali, kepadatan penduduk juga memacu perkembangbiakan jentik nyamuk Aedes aegypti, juga menyebabkan DBD di Indonesia sulit diberantas. Salah satu cara upaya pemberantasan nyamuk Aedes aegypti adalah memutus mata rantai penyebaran nyamuk Aedes aegypti dengan cara memberantas sarang nyamuk dan membunuh larva serta nyamuk dewasa. Penggunaan insektisida dan pestisida sebagai larvasida merupakan cara paling umum dalam pengendalian vektor, biasanya menggunakan abate dan temephos (organophospat).

Beberapa penelitian menunjukkan telah terjadi resistensi larva terhadap pestisida dan kandungan kimia sintetik temephos dan abate dalam jangka waktu lama menyebabkan kanker (Mulyatno, et.al., 2012; Panghiyangani, et.al., 2014 dalam Adrianto, et.al., 2014).

Bahan alternatif lain diperlukan untuk mencegah resistensi serta mengendalikan vektor secara lebih aman, sederhana dan ramah lingkungan, biolarvasida dengan bahan dasar tumbuhan merupakan alternatif lain yang bisa digunakan. Indonesia kaya akan flora mempunyai berbagai jenis tanaman yang berpotensi sebagai obat-obatan dan biolarvasida. Biolarvasida membunuh serangga melalui berbagai cara, diantaranya sebagai racun kontak yang masuk melalui kulit atau dinding tubuh, maupun sebagai racun perut atau mulut yang masuk melalui alat pencernaan. Tanaman yang sering digunakan salah satunya adalah jeruk purut, baik dari buah maupun daunnya. Beberapa penelitian telah dilakukan sebelumnya baik yang meneliti kandungan maupun keefektifan dari jeruk purut sebagai biolarvasida.

\section{METODE PENELITIAN}

Jenis penelitian ini adalah deskriptif, data diperoleh secara studi pustaka dengan menggunakan data dari beberapa jurnal penelitian sebelumnya.

\section{HASIL PENELITIAN}

Kandungan senyawa kimia pada jeruk purut yang dapat digunakan sebagai biolarvasida meliputi senyawa minyak atsiri, flavonoid, saponin dan terpen pada daun jeruk purut yang bekerja sebagai racun pada larva nyamuk baik sebagai racun kontak maupun racun perut. Senyawa flavonoid dapat menembus kutikula larva nyamuk kemudian merusak membran sel larva nyamuk. Senyawa saponin dalam ekstrak dapat mengiritasi mukosa traktus digestivus larva dan merusak membran sel larva bila terminum oleh larva. Limonoid merupakan minyak esensial dalam jeruk dapat menyebabkan hilangnya koordinasi organ larva nyamuk (Adrianto, et al., 2014). Minyak atsiri daun jeruk purut efektif sebagai biolarvasida karena kandungan senyawa yang mudah menguap dan senyawa alelokimia seperti terpenoid, tannin yang akan menyebabkan larva tidak dapat mencapai berat kritisnya untuk menjadi pupa sehingga laju metabolisme menurun. Minyak daun jeruk purut diketahui mengandung beberapa senyawa antara lain sitronelal, linalool, sitronelol, sitronelil asetat, kariofilin dan geraniol. Sitronelal sebagai racun kontak, bila dalam konsentrasi tinggi dapat menyebabkan kematian. 


\section{PEMBAHASAN}

Hasil penelitian yang dilakukan yang dilakukan Hamidah, 2012 menunjukkan bahwa ekstrak kulit buah jeruk purut lebih toksik dan mempunyai daya biolarvasida yang tinggi terhadap larva nyamuk Aedes aegypti. Minyak daun jeruk purut memiliki potensi sebagai biolarvasida terhadap larva instar III nyamuk Ae. aegypti. Kenaikan konsentrasi minyak akan menunjukkan kandungan bahan aktif yang terkandung dalam larutan uji semakin besar dan mengganggu kerja sistem fisiologis larva, sehingga jumlah larva yang mati akan semakin meningkat dikarenakan bahan aktif yang terpapar pada tubuh nyamuk lebih banyak. Hasil penelitian Istianah, et al, 2012 menunjukkan bahwa nilai Lethal Concentration $\quad\left(\mathrm{LC}_{50}\right) \quad$ merupakan konsentrasi dari minyak daun jeruk purut yang menyebabkan larva mati $50 \%$ dari jumlah sampel penenlitian selama waktu perlakuan, hasil analisis menunjukkan bahwa $\mathrm{LC}_{50}$ dari minyak daun jeruk purut sebagai biolarvasida terhadap larva instar III nyamuk Ae. Aegypti adalah 279,882 ppm. Hasil penelitian Anggraini, et al., 2012 menunjukkan hasil bahwa ekstrak daun jeruk purut memiliki nilai toksisitas biolarvasida $\left(\mathrm{LC}_{90}\right)$ sebesar $4000 \mathrm{ppm}$ dengan masa letal $\left(\mathrm{LT}_{90}\right) 12.67 \mathrm{jam}$. Hal ini disebabkan ekstrak daun jeruk purut tidak hanya menghasilkan senyawa limonoida namun juga menghasilkan minyak atsiri dan menghasilkan senyawa tidak aktif yang dapat membantu meningkatkan aktivitas ekstrak secara keseluruhan, sehingga memungkinkan serangga tidak mudah resisten. Minyak atsiri yang dihasilkan dari ekstrak daun jeruk purut merupakan lapisan minyak yang menyebabkan larva terhalang saat mencari udara, ketika larva menempel pada permukaan air (larutan ekstrak), siphon larva akan tertutupi oleh lapisan minyak sehingga menghalangi proses difusi masuknya oksigen dalam tubuh yang dibutuhkan oleh larva maka larva akan mati (Sungkar, et al, 2008 dalam Anggraini, et al., 2012).

\section{KESIMPULAN DAN SARAN}

Berdasarkan kajian dan data-data hasil penelitian beberapa peneliti dapat disimpulkan bahwa tanaman jeruk purut mempunyai senyawa-senyawa kimia yang mempunyai potensi sebagai biolarvasida nyamuk. Saran penelitian selanjutnya pemilihan metode ekstraksi yang digunakan yang bisa diaplikasikan oleh masyarakat sehingga bisa sebagai alternatif pilihan biolarvasida.

\section{DAFTAR RUJUKAN}

Adrianto, H., Yotopranooto, S., Hamidah., 2014. Efektifitas Ekstrak Daun Jeruk Purut (Cytrus hystrix), Jeruk Limau (Citrus amblycarpa), dan Jeruk Bali (Citrus maxima) Terhadap Larva Aedes aegypti. Aspirator.Vol 6 (1) : 1-6

Anggraini, A., Hamidah, Moehammadi, N., 2012. Uji Efektifitas Ekstrak Daun Jeruk Purut (Cytrus hystrix D.C.) dan Daun Jeruk Kalamondin (Citrus mitis Blanco) Sebagai Biolarvasida Terhadap Kematian Larva Instar III Nyamuk Aedes aegypti. Fakultas Kedokteran. Universitas Airlangga. Surabaya.

Istianah, MA., Utami, W.S., Ameliana, L., 2013. Efektifitas Biolarvasida Minyak Daun Jeruk Purut ( Citrus hystrix) Terhadap Larva Instar III Nyamuk Aedes aegypti.. Fakultas Kedokteran. Universitas Jember. Jember. 